\title{
The Electrocardiogram in Chronic Bronchitis and Emphysema
}

\author{
A. G. CHAPPELL* \\ From Bridgend General Hospital, Glamorgan.
}

A study has been made of the electrocardiogram in patients primarily suffering from chronic bronchitis. Airways obstruction and emphysema existed to a variable degree in these patients, and an attempt is made to assess the influence of these factors on the electrocardiogram.

Earlier papers relating to electrocardiographic changes in chronic bronchitis, emphysema, and other chronic forms of pulmonary disease are numerous. Scott (1961), in a good summary, refers to $P$ pulmonale, prominent $\mathrm{Ta}$ waves, rightward deviation of the $P$ axis and mean frontal QRS axis, low voltage QRS complexes, negative W shaped, or transitional (QS, rSR, QRS, RS) complexes in the præcordial leads, $\mathrm{rSR}^{\prime}$ in V1, incomplete or complete right bundle-branch block, classical right ventricular hypertrophy with dominant $R$ in $V 1$ with or without $T$ wave inversion in right præcordial leads, and abnormal left axis deviation.

Factors thought to explain these changes include dilatation and/or hypertrophy of the right atrium and right ventricle, diminished electrical conductivity by the emphysematous lung (supported by the experimental studies of Schwan and Kay, 1956), and altered position of the heart (clockwise rotation, vertical position, and backward rotation of the apex consequent on low diaphragms and hyperinflation of the lungs). The heart may certainly lie low in the chest in emphysema, thus accounting for predominantly negative QRS complexes to V5 or V6 ("clockwise rotation"). However, attempts to assess rotation in coronal and sagittal planes by correlation of the anatomical axis of the heart, obtained from anterior and lateral radiographs of the chest, with the electrical axis (Hyman, Failey, and Ashman, 1948; Fowler and

Received September 29, 1965.

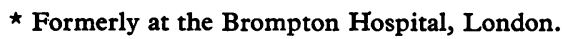

Braunstein, 1951), are clearly subject to considerable error, since there is no way of locating the interventricular septum. Grant (1953), in a series of careful anatomical studies, found little correlation between the electrical (mean QRS) and anatomical axes, and Guntheroth, Ovenfors, and Ikkos (1961) reached similar conclusions as a result of biplane angiocardiographic studies in children.

The continued search for electrocardiographic signs of right ventricular hypertrophy reflects the difficulty of diagnosing the condition especially in acquired as opposed to congenital heart disease. The subject has been critically reviewed by Scott (1960). F. J. C. Millard (1964, personal communication) has made a detailed electrocardiographic and pathological study of right ventricular hypertrophy in adult patients with chronic pulmonary disease, using an accurate method of assessment of ventricular weight (Fulton, Hutchinson, and Jones, 1952). A mean $Q R S$ axis between $+91^{\circ}$ and $+180^{\circ}$ was found in 85 per cent of patients with isolated right ventricular hypertrophy and in no patients without right ventricular hypertrophy. There was little correlation between the degree of QRS axis shift to the right and the severity of right ventricular hypertrophy. The electrocardiogram was not helpful in diagnosing right ventricular hypertrophy in patients with biventricular hypertrophy. Millard concluded that in chronic pulmonary disease the position of the mean QRS axis provided as good an indication of right ventricular hypertrophy as any other electrocardiographic sign.

\section{SUBJECTS AND METHODS}

The 112 patients studied, 91 men and 21 women, were aged from 24 to 72 years. All had chronic bronchitis, as defined at the Ciba Guest Symposium (1959), but no other known or suspected pulmonary disease, rheumatic or ischæmic heart disease, or hyptertension (defined as a diastolic blood pressure of $110 \mathrm{~mm}$. Hg or more). The 
patients had all been referred to the hospital out-patient department by their practitioners, and they were studied when in their optimum clinical state. Since the investigation began in 1961,10 have died. Histories were recorded on the M.R.C. Short Questionnaire on Respiratory Symptoms (1960).

Radiographs were assessed independently for emphysema and classified as normal, possible slight, localized, or widespread, according to criteria (signs of hyperinflation, pulmonary vascular changes, avascular areas) described by Simon (1964). The validity of this interpretation has been confirmed by the radiographic and pathological study of Reid and Millard (1964).

Peak expiratory flow rates (PEF) were measured with Wright's flowmeter (Wright and McKerrow, 1959). The forced expiratory volume in 1 second $\left(\mathrm{FEV}_{1}\right)$ was also recorded since it is a more discriminating test of respiratory function (Fairbairn et al., 1962).

Electrocardiograms were recorded with Sanborn direct writers employing conventional standardization $(1 \mathrm{~cm} .=1 \mathrm{mV})$. They were analysed for the following features:

(1) $P$ pulmonale (peaked $P>2.5 \mathrm{~mm}$. high in any standard limb lead).

(2) $P$ axis calculated by the method of Grant (1957). The normal limits of $P$ axis were taken as $+15^{\circ}$ to $+75^{\circ}$ (Chevalier and Thaon, 1949; Masini and Rossi, 1951 ; Hiss, Lamb, and Allen, 1960).

(3) Mean frontal $Q R S$ axis by the method of Grant (1950). The normal range was considered to be $-30^{\circ}$ to $+90^{\circ}$. QRS axes between $-30^{\circ}$ and $-90^{\circ}$ indicate abnormal left axis deviation and between $+91^{\circ}$ and $+180^{\circ}$ right ventricular hypertrophy (F. J. C. Millard, 1964, personal communication).

(4) Other abnormalities. The criteria for right bundle-branch block (RBBB) were: QRS duration $>$ $0 \cdot 1$ sec., terminal slurred $S$ wave in lead I (terminal QRS vector between $+90^{\circ}$ and $-90^{\circ}$ ), and terminal $R$ waves in V1 and V2. $S_{1} S_{2} S_{3}$ syndrome refers to a condition in which the QRS complex is not prolonged, and there are terminal $S$ waves in leads I,II, and III (terminal $Q R S$ vector between $-90^{\circ}$ and $-150^{\circ}$ ).

\section{RESULTS}

Table I lists the main electrocardiographic findings in the 112 patients with chronic bronchitis divided according to radiographic criteria of emphysema previously described. Right ventricular hypertrophy (RVH), left axis deviation (LAD), $\mathbf{P}$ pulmonale, and rightward deviation of the $P$ axis (vertical $\mathrm{P}$ axis) occurred more frequently in the 24 patients with widespread emphysema than in the 88 chronic bronchitics with possible slight, localized, or no emphysema. (The differences are statistically significant in respect of left axis deviation, $P$ pulmonale, and vertical $P$ axis $; p=0.01,0.02,0.005$ respectively.)

Patients with widespread emphysema all had severe airways obstruction with peak expiratory flow rates less than 200 litres/min., $F_{1}$ less than $1,500 \mathrm{ml}$. (all but 2 less than 1,200 ml.), $\mathrm{FEV}_{1} /$ FVC ratios between 24 and 59 per cent (normal > $75 \%$ ), and absolute predicted $\mathrm{FEV}_{1}$ ratios between 17 and 45 per cent. (Predicted FEV 1 values based on age and height were those of $F$. I. Caird, 1964, personal communication.) The 88 chronic bronchitics with possible slight, localized, or no emphysema, had a much more variable degree of airways obstruction. They were separated into two groups; one comprised 43 patients with $\mathrm{PEF}<$ $2001 . / \mathrm{min}$. and $\mathrm{FEV}_{1}<1,200 \mathrm{ml}$., and the other 45 patients with $\mathrm{PEF}>200$ litres/min. and $\mathrm{FEV}_{1}>$ $1,200 \mathrm{ml}$. Table II compares the electrocardiographic changes in these two groups with the findings in the 24 patients with widespread emphysema. It shows no significant difference between the incidence of right ventricular hypertrophy, left axis deviation, $P$ pulmonale, and rightward deviation of $\mathbf{P}$ axis in patients with widespread emphysema and in chronic bronchitics with a similar degree of severe airways obstruction but less severe or no emphysema. Patients in the latter radiographic categories but with less severe

TABLE I

SUMMARY OF ELECTROCARDIOGRAPHIC FINDINGS IN 112 CHRONIC BRONCHITICS CLASSIFIED ACCORDING TO RADIOGRAPHIC APPEARANCES

\begin{tabular}{|c|c|c|c|c|c|c|c|c|c|c|c|}
\hline \multirow{2}{*}{\multicolumn{2}{|c|}{ Radiographic classification }} & \multirow{2}{*}{\multicolumn{2}{|c|}{$\begin{array}{c}\text { No. of } \\
\text { patients } \\
\text { Male Female }\end{array}$}} & \multirow{3}{*}{$\begin{array}{c}\begin{array}{c}\text { Age } \\
\text { (mean and } \\
\text { range) }\end{array} \\
\begin{array}{c}58 \cdot 3 \\
(42-72)\end{array}\end{array}$} & \multicolumn{4}{|c|}{ Mean frontal QRS axis } & \multirow{3}{*}{$\frac{\begin{array}{c}\text { P pul- } \\
\text { monale }\end{array}}{6}$} & \multicolumn{2}{|c|}{ Mean $P$ axis } \\
\hline & & & & & \multirow{2}{*}{$\begin{array}{r}+91^{\circ} \text { to } \\
+180^{\circ} \\
4\end{array}$} & \multirow{2}{*}{$\begin{array}{r}-30^{\circ} \text { to } \\
+90^{\circ} \\
14\end{array}$} & \multirow{2}{*}{$\frac{\begin{array}{l}-31^{\circ} \text { to } \\
-89^{\circ}\end{array}}{5}$} & \multirow{2}{*}{$\frac{-90^{\circ} \text { to }}{-180^{\circ}}$} & & \multirow{2}{*}{$\begin{array}{l}+76^{\circ} \text { to } \\
+90^{\circ} \\
13\end{array}$} & \multirow{2}{*}{$\begin{array}{r}0^{\circ} \text { to } \\
+75^{\circ} \\
11\end{array}$} \\
\hline Widespread emphysema & . & 22 & 2 & & & & & & & & \\
\hline $\begin{array}{l}\text { Possible slight emphysema } \\
\text { Localized emphysema .. } \\
\text { No emphysema }\end{array}$ & $\begin{array}{l}\cdots \\
\cdots\end{array}$ & $\begin{array}{l}6 \star \\
15 t \\
48\end{array}$ & 19 & $\begin{array}{c}55 \cdot 4 \\
(24-72)\end{array}$ & $\bar{z}$ & $\begin{array}{r}5 \\
10 \\
57\end{array}$ & $\begin{array}{l}\overline{1} \\
2\end{array}$ & $\overline{2 \ddagger}$ & $\begin{array}{l}\overline{2} \\
3\end{array}$ & $\begin{array}{l}3 \\
7 \\
9\end{array}$ & $\begin{array}{r}3 \\
8 \\
58\end{array}$ \\
\hline
\end{tabular}

$\star 1$ QRS axis indeterminate.

+2 ORS axes indeterminate.

Includes 1 case of right bundle-branch block. 
TABLE II

MAIN ELECTROCARDIOGRAPHIC FINDINGS IN CHRONIC BRONCHITICS WITH WIDESPREAD EMPHYSEMA, AND CHRONIC BRONCHITICS WITH LESS SEVERE OR NO EMPHYSEMA, DIVIDED ACCORDING TO SEVERITY OF AIRWAYS OBSTRUCTION

\begin{tabular}{|c|c|c|c|c|c|c|c|}
\hline & $\begin{array}{l}\text { No. of } \\
\text { patients }\end{array}$ & $\begin{array}{c}\text { Right } \\
\text { ventricular } \\
\text { hypertrophy }\end{array}$ & $\begin{array}{l}\text { Normal } \\
\text { QRS axis }\end{array}$ & $\begin{array}{l}\text { Left axis } \\
\text { deviation }\end{array}$ & P pulmonale & $\begin{array}{c}\text { Rightward } \\
\text { deviation of } P \text { axis }\end{array}$ & $\underset{P \text { axis }}{\text { Normal }}$ \\
\hline Widespread emphysema & 24 & $4(17 \%)$ & 14 & $5(21 \%)$ & $6(25 \%)$ & $13(54 \%)$ & 11 \\
\hline $\begin{array}{l}\text { Possible slight, localized, or no em- } \\
\text { physema (PEF }<2001 / \mathrm{min} \text {. FEV } \\
<1,200 \mathrm{ml} .) \\
\text { Possible slight, localized, or no em- } \\
\text { physema (PEF }>2001 / \mathrm{min} \text {. FEV } \\
>1,200 \mathrm{ml} .) \\
\begin{array}{l}\text {.. } \\
\text {. }\end{array}\end{array}$ & 43 & $7(16 \%)$ & 23 & $\begin{array}{l}3(7 \%) \\
0\end{array}$ & $\begin{array}{l}5(12 \%) \\
0\end{array}$ & $\begin{array}{l}16(37 \%) \\
3(7 \%)\end{array}$ & $\begin{array}{l}27 \\
42\end{array}$ \\
\hline
\end{tabular}

or no airways obstruction had virtually normal electrocardiograms. As expected from these findings, the correlations of these four main electrocardiographic abnormalities with severe breathlessness (Grades 4, 5 dyspnœa), PEF $<200$ l./min., and $\mathrm{FEV}_{1}<1,200 \mathrm{ml}$. are statistically significant ( $p$ varying from 0.0005 to 0.05 ). There was, however, no significant association between $P$ pulmonale and vertical $P$ axis and the various $Q R S$ abnormalities (right ventricular hypertrophy, left axis deviation, right bundle-branch block, $S_{1} S_{2} S_{3}$ syndrome, and indeterminate QRS axis).

Other Abnormalities. Excluding right ventricular hypertrophy, 4 tracings showed isoelectric or inverted $T$ waves in various leads, presumably due to ischæmia, and in a further 9 there were small secondary $r$ waves in the right præcordial leads. Ventricular ectopic beats occurred in 10 electrocardiograms. During acute exacerbations of bronchitis one patient had atrial flutter, and another had paroxysmal atrial fibrillation, but there were no persistent arrhythmias. There were 2 cases of right and one of left bundle-branch block. The mean QRS axis was indeterminate in 3 patients. One of these and 2 others with mean QRS axes of $-100^{\circ}$ and $-120^{\circ}$ were examples of the $S_{1} S_{2} S_{3}$ syndrome. Left axis deviation deserves special mention. The mean $Q R S$ axis was $-35^{\circ}$ (later $-85^{\circ}$ ), $-35^{\circ}$, $-50^{\circ},-60^{\circ}$, and $-60^{\circ}$, respectively, in 5 patients with widespread emphysema. Two of these had isœlectric $\mathrm{T}$ waves in lead $\mathrm{I}$ ( $\mathrm{T}$ vector $+90^{\circ}$; wide QRS-T angle), possibly indicating myocardial ischæmia. In the other 3 patients, there was no obvious cause for the left axis deviation. Three patients with localized or no emphysema had mean QRS axes of $-40^{\circ},-45^{\circ}$ and $-70^{\circ}$. The first also had a $\mathrm{T}$ vector of $+90^{\circ}$ and the second showed antero-lateral peri-infarction block.

\section{Discussion}

Rightward deviation of the $\mathbf{P}$ axis in chronic pulmonary disease has been noted by Novelo
(1945), Zuckermann et al. (1948), Vaquero (1948), Lenègre, Maurice, and Scebat (1954), and Littmann (1960). Caird and Wilcken (1962) who also confined their investigation to patients with chronic bronchitis, found a $\mathrm{P}$ axis of $+80^{\circ}$ or more in 29 $(50 \%)$ of 58 cases, but there was no relation between the $\mathbf{P}$ axis and ventilatory function as measured by $\mathrm{FEV}_{1}$. Spodick et al. (1963) observed a $\mathrm{P}$ axis of $+70^{\circ}$ to $+90^{\circ}$ in $220(73 \%)$ of 301 cases of "pulmonary emphysema", and there was significant correlation between vertical $P$ axis and increasing severity of airways obstruction. In our study, a $\mathrm{P}$ axis between $+75^{\circ}$ and $+90^{\circ}$ occurred in only $32(29 \%)$ of 112 patients. It correlated well with severe dyspnœa and airways obstruction but not with cardiographic right ventricular hypertrophy. The significantly higher incidence of vertical $P$ axis in patients with widespread emphysema as opposed to those with slight, localized, or no emphysema, was a reflection of the uniformly severe airways obstruction found in the former group. $\mathrm{P}$ pulmonale, which was found in only 10 per cent of our patients, was always associated with marked impairment of ventilatory capacity.

The small $(<5 \mathrm{~mm}$.) secondary $r$ waves found in $\mathrm{V} 1$ or V2 in the absence of signs of right ventricular hypertrophy, right bundle-branch block, periinfarction block, or other evidence of coronary artery disease, were presumably a normal finding (Camerini and Davies, 1955; Said and Bryant, 1956) though Mounsey, Ritzmann, and Selverstone (1952) found that their occurrence in chronic pulmonary disease was often a stage in the development of a classical right ventricular hypertrophy pattern. Right bundle-branch block occurred in 2 patients. It has been suggested that right ventricular hypertrophy may be diagnosed in the presence of $R B B B$ if the secondary $r$ wave in V1 exceeds $15 \mathrm{~mm}$. in amplitude $(10 \mathrm{~mm}$. if QRS duration less than 0.12 sec.-Barker and Valencia, 1949). However, the findings of Dodge and Grant (1956) and those of Booth, Chou, and Scott (1958) do not support this view. 
The occurrence of left axis deviation in chronic pulmonary disease has been recorded by Lenègre et al. (1954), Coelho et al. (1962), and Banta, Greenfield, and Estes (1964). It may be due to associated left ventricular hypertrophy or ischæmic heart disease with myocardial fibrosis. There was no clinical or electrocardiographic evidence of these conditions in 4 of our 8 patients with left axis deviation. Two of these patients have died: at necropsy one was found to have normal coronary arteries and a normal myocardium, and in the other myocardial fibrosis was present. Other suggested mechanisms of left axis deviation include altered position of the heart (Wasserburger et al., 1959; Burch and DePasquale, 1963), right ventricular hypertrophy (Lasser and Grishman, 1951; Curd, Hicks, and Gyorkey, 1961), and poor electrical conduction by the emphysematous or hyperinflated lung with "verticalization" of the electric field, and the axis illusion phenomenon (Grant, 1956; Talbot and Leonard, 1958; Spodick, 1959; Littmann, 1960). Some of these authors also mention the occurrence of indeterminate mean QRS axes, and $\mathrm{S}_{1} \mathrm{~S}_{2} \mathrm{~S}_{3}$ patterns. In patients with chronic pulmonary disease, the $S_{1} S_{2} S_{3}$ syndrome may indicate right ventricular hypertrophy (Schwartz and Marcus, 1942; Carouso, Tilmant, and Lenègre, 1949; Pryor, 1964), but it may also occur in normal people, in congenital heart disease with right ventricular hypertrophy, and in myocardial infarction (Sodi-Pallares, 1956; Grant, 1957).

There was no significant difference in the incidence of right ventricular hypertrophy in chronic bronchitis with widespread emphysema and similarly disabled patients with less severe or no emphysema. This finding is contrary to commonly held views and comparable published work, which indicate a much higher incidence of right ventricular hypertrophy in chronic bronchitics without radiographic emphysema (Fletcher et al., 1963; Burrows et al., 1964). The electrocardiographic criteria of Goodwin and Abdin (1959) were used for the diagnosis of right ventricular hypertrophy in these authors' series, but if applied to the 112 patients in this study an even higher incidence of right ventricular hypertrophy would result (Table III) in those with widespread emphysema.

The finding is clearly not due to the selective inclusion of a large number of patients with widespread emphysema in the present study, since the proportion with this radiographic abnormality $(21 \%)$ is similar to that found $(14-29 \%)$ in 4 other series comprising 1,431 patients with chronic bronchitis (Simon and Galbraith, 1953; Simon and
Medvei, 1962; Fletcher et al., 1964; Burrows et al., 1965). There were no significant differences in age, mean transverse diameter of heart, and number of incidents of cardiac failure in our patients with right ventricular hypertrophy in association with widespread emphysema, and right ventricular hypertrophy with less severe or no emphysema, though the duration of symptoms was greater in the former group.

\section{TABLE III}

INCIDENCE OF RIGHT VENTRICULAR HYPERTROPHY (CRITERIA OF GOODWIN AND ABDIN, 1959) IN 112 CHRONIC BRONCHITICS

\begin{tabular}{l|c|c|c}
\hline Radiographic classification & $\begin{array}{c}\text { No. of } \\
\text { patients }\end{array}$ & $\begin{array}{c}\text { Right } \\
\text { (grade I) } \\
\text { ventricular } \\
\text { hypertrophy }\end{array}$ & $\begin{array}{c}\text { Right } \\
\text { (grades 2-4) } \\
\text { ventricular } \\
\text { hypertrophy }\end{array}$ \\
\hline $\begin{array}{l}\text { Widespread emphysema } \\
\text { Slight, localized, or no } \\
\text { emphysema . . }\end{array}$ & 24 & 5 & 6 \\
\hline
\end{tabular}

\section{SUMMARY}

An electrocardiographic study has been made of 112 hospital out-patients suffering from chronic bronchitis. Rightward deviation of the $P$ axis occurred in $32(29 \%)$ patients, $P$ pulmonale in 11 $(10 \%)$, right ventricular hypertrophy in $11(10 \%)$, and left axis deviation in $8(7 \%)$. Less common abnormalities included small secondary $r$ waves in right præcordial leads, right and left bundle-branch block, indeterminate mean QRS axes, and $S_{1} S_{2} S_{3}$ syndrome. Rightward deviation of the $P$ axis, $P$ pulmonale, and right ventricular hypertrophy were confined to patients with severe airways obstruction, and the presence or absence of widespread emphysema assessed radiographically did not appear to influence these electrocardiographic abnormalities. In so far as right ventricular hypertrophy is concerned, this finding is contrary to previously published evidence. Left axis deviation may be the sole electrocardiographic abnormality and the possible mechanisms concerned are discussed.

I am grateful to Dr. J. C. Batten for permission to study his patients at the Brompton Hospital, to Dr. G. Simon for interpreting the X-rays, and to Dr. Batten, Dr. W. Phillips, and Dr. A. Leatham for much helpful criticism and advice in the preparation of this paper.

\section{REFERENCES}

Banta, H. D., Greenfield, J. C., and Estes, E. H. (1964). Left axis deviation. Amer.F. Cardiol., 14, 330.

Barker, J. M., and Valencia, F. (1949). The precordial electrocardiogram in incomplete right bundle branch block. Amer. Heart f., 38, 376. 
Booth, R. W., Chou, T. C., and Scott, R. C. (1958). Electrocardiographic diagnosis of ventricular hypertrophy in the presence of right bundle-branch block. Circulation, 18, 169.

Burch, G. E., and DePasquale, N. P. (1963). The electrocardiographic diagnosis of pulmonary heart disease. Amer.F. Cardiol., 11, 622.

Burrows, B., Niden, A. H., Barclay, W. R., and Kasik, J. E. (1965). Chronic obstructive lung disease I. Clinical and physiological findings in 175 patients and their relationship to age and sex. Amer. Rev. resp. Dis., 91, 521.

,$--\frac{1}{-}$, Fletcher, C. M., and Jones, N. L. (1964). Clinical types of chronic obstructive lung disease in London and in Chicago. A study of 100 patients. Amer. Rev. resp. Dis., 90, 14.

Caird, F. I., and Wilcken, D. E. L. (1962). The electrocardiogram in chronic bronchitis with generalized obstructive lung disease. Its relation to ventilatory function. Amer. F. Cardiol., 10, 5.

Camerini, F., and Davies, L. G. (1955). Secondary R waves in right chest leads. Brit. Heart F., 17, 28.

Carouso, G., Tilmant, J., and Lenègre, J. (1949). Signification des ondes $\mathrm{S}_{1} \mathrm{~S}_{2}$ et $\mathrm{S}_{3}$ prédominantes. Arch. Mal. Cour, 42, 418.

Chevalier, H., and Thaon, M. (1949). Le vecteur ÂP manifeste (grandeur et direction) calculé sur 180 cœurs normaux entre 12 et 65 ans. Arch. Mal. Cour, 42, 333.

Ciba Guest Symposium (1959). Terminology, definitions, and classification of chronic pulmonary emphysema and related conditions. Thorax, 14, 286.

Coelho, E., Amram, S. S., E Sa, A. B., Mendes, J. C. F., and Tavares, V. (1962). Electrocardiographic and vectorcardiographic alterations in chronic cor pulmonale. Amer.F. Cardiol., 10, 20.

Curd, G. W., Hicks, W. M., and Gyorkey, F. (1961). Marked left axis deviation. Indication of cardiac abnormality. Amer. Heart f., 62, 462.

Dodge, H. T., and Grant, R. P. (1956). Mechanisms of QRS complex prolongation in man. Right ventricular conduction defects. Amer. F. Med., 21, 534.

Fairbairn, A. S., Fletcher, C. M., Tinker, C. M., and Wood, C. H. (1962). A comparison of spirometric and peak expiratory flow measurements in men with and without chronic bronchitis. Thorax, 17, 168.

Fletcher, C. M., Hugh-Jones, P., McNicol, M. W., and Pride, N. B. (1963). The diagnosis of pulmonary emphysema in the presence of chronic bronchitis. Quart. $\mathcal{F}$. Med., 32, 33.

—, Jones, N. L., Burrows, B., and Niden, A. H. (1964). American emphysema and British bronchitis. A standardized comparative study. Amer. Rev. resp. Dis., 90, 1.

Fowler, N. O., and Braunstein, J. R. (1951). Anatomic and electrocardiographic position of the heart. Circulation, 3, 906.

Fulton, R. M., Hutchinson, E. C., and Jones, A. M. (1952). Ventricular weight in cardiac hypertrophy. Brit. Heart F., 14, 413.

Goodwin, J. F., and Abdin, Z. H. (1959). The cardiogram of congenital and acquired right ventricular hypertrophy. Brit. Heart f., 21, 523.

Grant, R. P. (1950). Spatial vector electrocardiography. A method for calculating the spatial electrical vectors of the heart from conventional leads. Circulation, 2, 676 . (1953). The relationship between the anatomic position of the heart and the electrocardiogram. A criticism of "unipolar" electrocardiography. Circulation, 7, 890.
(1956). Left axis deviation. An electrocardiographicpathologic correlation study. Circulation, 14, 233.

(1957). Clinical Electrocardiography. The Spatial Vector Approach. McGraw-Hill Book Co., New York.

Guntheroth, W. G., Ovenfors, C., and Ikkos, D. (1961). Relationship between the electrocardiogram and the position of the heart as determined by biplane angiocardiography. Circulation, 23, 69.

Hiss, R. G., Lamb, L. E., and Allen, M. F. (1960). Electrocardiographic findings in 67,375 asymptomatic subjects. X. Normal values. Amer. F. Cardiol., 6, 200.

Hyman, A., Failey, R. B., and Ashman, R. (1948). Can the longitudinal anatomical axis of the ventricles be estimated from the electrocardiogram? Amer. Heart f., 36, 906 .

Lasser, R. P., and Grishman, A. (1951). Vectorcardiograms obtained in patients with right ventricular hypertrophy whose electrocardiograms display an unusual axis deviation or left axis deviation. Amer. Heart f., 41, 901.

Lenègre, J., Maurice, P., and Scebat, L. (1954). Les stades initiaux du cœur pulmonaire chronique. Acta cardiol. (Brux.), 9, 314.

Littmann, D. (1960). The electrocardiographic findings in pulmonary emphysema. Amer. F. Cardiol., 5, 339.

Masini, V., and Rossi, B. (1951). L'onda atriale dell' elettrocardiogramma I. Morfologia ed elettrofisiologia dell' onda P nei soggetti normali. Cuore e Circol., 35, 24.

Medical Research Council (1960). Standardized questionnaries on respiratory symptoms. Brit. med. $\mathcal{F}$., 2, 1665.

Mounsey, J. P. D., Ritzmann, L. W., and Selverstone, N. J. (1952). Cardiographic studies in severe pulmonary emphysema. Brit. Heart f., 14, 442.

Novelo, S. (1945). La onda P-pulmonar. Estudio comparativo de la onda $P$ en los enfermos mitrales y pulmonares cronicos. Arch. Inst. Cardiol. Méx., 15, 179.

Pryor, R. (1964). The $S_{1}, S_{2}, S_{3}$ syndrome in chronic pulmonary disease. Dis. Chest, 46, 226.

Reid, L., and Millard, F. J. C. (1964). Correlation between radiological diagnosis and structural lung changes in emphysema. Clin. Radiol., 15, 307.

Said, S. I., and Bryant, J. M. (1956). Right and left bundlebranch block in young healthy subjects. Circulation, 14, 993.

Schwan, H. P., and Kay, C. F. (1956). Specific resistance of body tissues. Circulat. Res., 4, 664 .

Schwartz, S. P., and Marcus, H. (1942). The electrocardiogram in pulmonary tuberculosis. Amer. Rev. Tuberc., 46, 35 .

Scott, R. C. (1960). The correlation between the electrocardiographic patterns of ventricular hypertrophy and the anatomic findings. Circulation, 21, 256.

- (1961). The electrocardiogram in pulmonary emphysema and chronic cor pulmonale. Amer. Heart F., 61, 843.

Simon, G. (1964). Radiology and emphysema. Clin. Radiol., 15, 293.

, and Galbraith, H.-J. B. (1953). Radiology of chronic bronchitis. Lancet, 2,850 .

, and Medvei, V. C. (1962). Chronic bronchitis; radiological aspects of a five-year follow-up. Thorax, 17, 5 .

Sodi-Pallares, D. (1956). New Bases of Electrocardiography, p. 276. Henry Kimpton, London.

Spodick, D. H. (1959). Electrocardiographic studies in pulmonary disease. I. Electrocardiographic abnormalities in diffuse lung disease. Circulation, 20, 1067. 
- - Hauger-Klevene, J. H., Tyler, J. M., Muench, H., and Dorr, C. A. (1963). The electrocardiogram in pulmonary emphysema. Relationship of characteristic electrocardiographic findings to severity of disease as measured by degree of airway obstruction. Amer. Rev. resp. Dis., 88, 14.

Talbot, F. J., and Leonard, J. J. (1958). Severe left axis deviation in the presence of pulmonary emphysema. Circulation, 18, 787.

Vaquero, M. (1948). Estudio clinico y radiologico de 150 casos de "cor pulmonale cronico". Arch. Inst. Cardiol. Méx., 18, 763.
Wasserburger, R. H., Kelly, J. R., Rasmussen, H. K., and Juhl, J. H. (1959). The electrocardiographic pentalogy of pulmonary emphysema; A correlation of roentgenographic findings and pulmonary function studies. Circulation, 20, 831.

Wright, B. M., and McKerrow, C. B. (1959). Maximum forced expiratory flow rate as a measure of ventilatory capacity with a description of a new portable instrument for measuring it. Brit. med.F., 2, 1,041.

Zuckermann, R., Cabrera, E., Fishleder, B. L., and SodiPallares, D. (1948). Electrocardiogram in chronic cor pulmonale. Amer. Heart. F., 35, 421. 